\title{
Beyond Exception and Supremacy: Adwa in the Black Radical Imaginary
}

\author{
Michael Girma Kebede ${ }^{1}$
}

\begin{abstract}
Stories of Adwa have anchored multiple forms of exceptionalism that underpin some Ethiopians' sense of superiority over others of African descent. This narrative mode goes hand-in-hand with certain toxic, solidarity destroying tendencies of some diasporic Ethiopians. Following the methodology of Tizita, innovated in Centime Elleni Zeleke's Ethiopia in Theory, I analyse two such tendencies, social distancing and victim-blaming, in some depth. These forms of enacted exceptionalism weaken social movements like Black Lives Matter. This article offers a way out by thinking of Adwa as part of the black radical imaginary, a concept I develop drawing on the thinking of Cedric Robinson and Robin DG Kelley, and recent work by political theorists Paula Diehl and Craig Browne. The Battle of Adwa was one episode in a centuries-long process of resistance to racial capitalist patriarchy, a world system that still persists in many ways. Adwa must also be re-narrated if it is to be a viable source of solidarity among Ethiopians and within Ethiopia. Re-narrating Adwa with an eye toward non-Amhara and nonTigre, and toward the anonymous, contributors to collective self-defense, is one way to tell a story geared toward an egalitarian politics focused on redressing historic wrongs. Gigi comes close to such a reading in her song Adwa.
\end{abstract}

Keywords: Adwa, black radical imagination, exceptionalism, imaginary, racial capitalist patriarchy, supremacy, Tizita

DOI: https://dx.doi.org/10.1314/ejossah.v17i1.3

\footnotetext{
${ }^{1}$ The author is an independent scholar unaffiliated with an academic institution. He lives and works in Portland, Maine, U.S.A., as an attorney for the American Civil Liberties Union. None of the perspectives in this paper necessarily reflect the opinion of his employer. Email: michaelgkebede@gmail.com
}

This work is licensed to the publisher under the Creative CommonsAttribution-NonCommercialNoDerivs License. 


\section{Introduction}

In this article I explore a tension between a certain way of remembering Adwa and two felt moral obligations. The first is advancing black radical feminist social movements where I live in the West. The second is to adopt and enshrine a representative vision of Ethiopian history. The "tension" is embodied in my heart, my mind, and my experiences of Ethiopianness, Oromoness, Amharaness, U.S. American blackness and participation in the Black Lives Matter movement in the United States. I follow a methodology pioneered in Elleni Centime Zeleke's Ethiopia in Theory, which proposes Tizita as a methodological alternative to positivist empiricism. Tizita turns the Amharic word for nostalgia into a research method whereby memory is given primacy as a form of embodied knowledge. Positivist empiricism, in contrast to Tizita's focus on the subjective making of meanings, emphasizes a conception of social reality as an objective fact that is scientifically verifiable. The ideas that animate this article also animate an ongoing debate between the wing of my family that attempts to practice solidarity with the most marginalized members of our political economy and the wing that indulges a sense of superiority over others. This sense of superiority is sometimes rooted in the historical memory of the Battle of Adwa, especially in an uncritical tendency to aggrandize Menelik.

I explore the way that Adwa may serve the sinister, solidarity-destroying tendency of some Ethiopians to see themselves as exceptional in contrast to practically all other people who have been racialized as black. This hierarchizing tendency is, of course, as common as dirt; I focus on a certain subset of Ethiopians because they are the people I know most intimately. In my exploration, I draw and expand on Adom Getachew's fruitful engagement with Elleni Centime Zeleke's Ethiopia in Theory, where Getachew gave a pithy description of Ethiopian exceptionalism. I then propose an alternative reading of Adwa through a concept I call the black radical imaginary.

This concept is rooted in Cedric Robinson's notion of the black radical tradition and the work of radical black feminists; it describes the psychic spaces that emerge in the process of resistance to racial capitalist patriarchy. In my reading, Adwa is not merely an encounter between Europe and Africa, or Italy and Abyssinia; Adwa is one episode in the centuries-long global assault of racial capitalism on the overwhelming majority of the peoples of the world, including Europeans themselves. Adwa stands alongside the innumerable triumphs over the would-be totalizing structures of racial capitalist domination. Arguments about the totalizing nature of racial capitalism, white supremacy, and other structures of domination have circulated for as long as these structures of domination have 
existed. Adwa is a rebuke to the notion of all-pervading domination, today perhaps most famously espoused by some scholars who call themselves Afropessimists.

Finally, I analyze an embodied tension between my assimilated Oromo mother and my dyed-in-the-wool Amhara father's relationship with Adwa. If this tension simmers in my family, it smolders and erupts in the Ethiopian political economy, where politics have been radically ethnicized for three decades. I analyze this tension through a reading of three cultural artifacts: songs about Adwa by Ijegayehu Shibabaw (Gigi) and Tewodros Kassahun (Teddy Afro), and a poem about Adwa by Poet-Laureate Tsegaye Gebre-Mhedin. Then I build on the work of several scholars in offering a way out.

\section{Methodology}

Throughout this article, I draw on autoethnography and Tizita. Under the first method, autoethnography, I use "personal experience as data to describe, analyze and understand cultural experience" (Campbell, 2016, p. 95). Under the second method, Tizita, I take seriously the contention that "[ $\mathrm{t}]$ he forcefield of the body is the sedimentation of world-historical conflict" (Zeleke, 2019, p. 36). Tizita explores and problematizes nostalgia (Zeleke, 2019, pp. 21-27). Unlike Zeleke, however, I excavate not a tragic but a romantic Tizita - a form of Tizita that carries in its train some of the hierarchizing violence of nationalist mythmaking. My exploration of Adwa is inextricable from my kin's nostalgia about, for, and around the event. The arguments herein are profoundly personal. They attempt to resolve tensions in society that I also embody.

My analysis of musical and poetic cultural artifacts is not, of course, an exhaustive or broadly representative analysis of culture in Ethiopia. Nor is it meant to imply analytical parity or identity between these genres of cultural output and, for example, peer-reviewed research papers. It is, rather, an attempt to engage in a targeted engagement with a dimension of cultural life in Ethiopia with artifacts whose popularity, especially among Amharic-speaking urban dwellers, and with diasporic Ethiopians, is difficult to deny. On Teddy Afro in particular, Hewan Semon Marye, in her incisive recent research, states that of the people she talked to during her research, "He is mentioned by every interviewee and in every single questionnaire and interview throughout" (Marye, 2019, p. 104, fn. 4).

\section{Adwa, Tizita, and two forms of exceptionalism}

In a recent review of Elleni Centime Zeleke's oracular Ethiopia in Theory, political scientist Adom Getachew writes "If Ethiopian studies is preoccupied with an exceptional non-blackness, in diasporic studies, Ethiopia stands for an exemplary 
Michael Girma Kebede

blackness-the sole African country that was never colonized" (2020). Some Ethiopian officials and nationalists alike have mobilized the memory of Adwa to reinforce both these forms of exceptionalism. But both these forms of exceptionalism rest on a foundation that may hurt possibilities for black solidarity across the black multiplicities of the contemporary world (Medford, 2019). Both of these forms of exceptionalism cut against what Tommie Shelby described as the common-oppression theory of black solidarity. In We Who Are Dark, Shelby argues that black solidarity should be rooted not in a common cultural identity, but in struggle against the common experience of anti-black systems, policies, and structures. Before describing the anti-solidaristic implications of exceptionalismrooted-in-Adwa, I will flesh out some of how Ethiopians enact this form of exceptionalism.

Tizita, Elleni Centime Zeleke's methodology, is instructive here. In my own experience as an Ethiopian born to Oromo and Amhara parents, raised in Addis Ababa on a heavy diet of Adwa-nostalgia, then transplanted to the west largely voluntarily, many older Ethiopians attempted to conscript me into the rarefied status of non-black Ethiopianness. "We are not like them," I have heard countless times. Ethiopians have recited similar lines to me in response to my attempts to enlist them in movements for black solidarity across socioeconomic and linguistic boundaries. Even eliciting rhetorical support for such movements has proved exceedingly difficult.

\section{Exceptional non-blackness: Uncolonized and unenslaved}

Adom Getachew's phrase, the "exceptional non-blackness" of Ethiopia, points to an idea that took root in a corner of Ethiopian political discourse during and stayed rooted long after the 1896 battle (Getachew, 2020). ${ }^{3}$ In the immediate aftermath of the Battle, newspapers across the western world scrambling to harmonize European defeat with ideas of black inferiority simply reclassified Ethiopians as white, or at least essentially non-black. Today it is common to hear Amharic-

\footnotetext{
${ }^{2}$ When I asked my Oromo mother and Amhara father what my ethnicity is, they recounted a story in which they told municipal workers in Addis that they have an Amhara daughter and an Oromo son -- each took one child. The municipal employees accepted the assignments, despite the patrilineal (and patriarchal) norms that supposedly governed such things in Ethiopian law.

${ }^{3}$ Daniel Selden's How the Ethiopian Changed his Skin describes the inverse process of how Axumites wrote themselves into a Hellenic Blackness as a way to increase cultural capital.
} 
speaking Ethiopians describe non-Arab and non-white Africans simply as "Africans," or "blacks," exempting themselves from either category (Woubshet, 2010, p. 200).

The idea of Ethiopian non-blackness has at least two insidious layers: the layer of the unenslaved and the layer of the uncolonized. The "unenslaved" layer radically distinguishes Ethiopians from those racialized in the Atlantic slave trade. The "uncolonized" layer radically distinguishes Ethiopians from those racialized through European colonialism. The idea beneath both these layers of nonblackness is that people whose ancestors did not pass through the formative experiences of enslavement or decades-long colonialism are fundamentally different from those whose ancestors did. But Ethiopians who live in the West, as well as those in Ethiopia whom the global relations of racial capitalism continue to marginalize and impoverish, have been and are on the receiving end of contemporary versions of the very forces that spawned European colonialism and the Atlantic slave trade. ${ }^{4}$

Indeed, votaries of the notion that Ethiopia represents an exceptional nonblackness make a tendentious and highly selective reading of the world-systems perspective of thinkers like Immanuel Wallerstien (1974), Cedric Robinson (1983), and Adom Getachew herself (2019). There is a racial capitalist world system, yes; they just read Ethiopia into its facets of triumph, but not into its facets of misery. Or perhaps they read Ethiopia the way Gibbon did, as "forgetful of the world [system], by whom they were forgotten" (1841), Adwa, and the expulsion of Italians in 1941, being the moments of mutual forgetting. Theirs is a form of provincialism that focuses trance-like on Adwa, while downplaying, rationalizing, or outright ignoring Europeans' gassing of Ethiopians in 1936, or the hugely lopsided, farmer-impoverishing terms of global trade for coffee, the world's second most widely traded commodity, or the implications for the past three decades of Ethiopian politics of the country's close alliance with the United States. These are just three macro-political examples of Ethiopians' imbrication in the world's centuries long racial capitalist world order.

Both these layers of supposed non-blackness - uncolonized and unenslaved - simultaneously make more and less of blackness than the world-systems, common-oppression idea makes of blackness. Placing undue emphasis on the

\footnotetext{
${ }^{4}$ Enslavement, was, of course present in Ethiopia and not abolished until well into the $20^{\text {th }}$ century. However, Ethiopian slavery was substantially different from the race-based chattel slavery of the Americas and of the Atlantic slave trade. It is against this latter experience that I argue some Ethiopians distinguish themselves from today to derive a definitive identity.
} 
theory that Ethiopians were neither colonized nor enslaved makes less of blackness because it ignores the harms that Ethiopians and their ancestors have suffered from European colonialism. Adwa itself was an invasion, after all - one in which Ethiopia suffered more deaths than did Italy. The world-systems theory of racialization widens the aperture on Ethiopians' suffering to reach beyond 1896 and encompass more events of degradation. Exceptional non-blackness makes more of blackness because the exceptionality of Ethiopians depends on the abasement of peoples who have supposedly been radically, ontologically altered by colonialism and slavery. But there is no such thing as permanent, unalterable degradation of a people. No historical trauma eternally fixes the identity of the colonized or the enslaved in the moment of defeat, or capture. Racial capitalism is powerful, but not all-powerful.

The consignment of colonized and enslaved peoples to the basement of history and human hierarchy serves a contradistinctive purpose. Under the exceptional non-blackness theory, Ethiopians can shine as triumphant only in contradistinction to the victims of European colonialism and the Atlantic triangle. This absurd perspective thinks of the forms of blackness that resulted from colonialism and the Atlantic slave trade as somehow lacking a special cultural sauce preserved by Ethiopia's triumph at Adwa. This absurdity ignores the fact that black people of the Americas, people whose ancestors were kidnapped in the Atlantic slave trade, have bequeathed their national and regional cultures, and indeed the global culture industry, all of which are profound contributions totally out of proportion with their numerical share in the hemisphere's population. Whether it is Reggae, Ska, or what W.E.B. DuBois called the "anointing chrism of the slave music, the only gift of pure art in America" (1998, p. 14), black people descended from enslaved Africans seem to be the ones with the special cultural sauce.

One of the fruits of the poisonous tree of Ethiopian non-blackness has been denial. The notion of Ethiopian non-blackness blinds Ethiopians to the roots of some of their suffering - and to some of the ways through, and out of, that suffering. "Yes, it is because you are black," I have had to tell some newcomers to the United States, where I have been living for over a decade. Mulugeta Seraw's death in 1988 at the hands of white supremacists in Oregon, as well of my own Ethiopian friend's subjection to physical and verbal violence at the hands of Hungarian skinheads in Budapest several years ago, exemplify one form of the anti-black violence to which people of African descent have been vulnerable for centuries. 
Another poisonous fruit of exceptional non-blackness has been the corrosion of opportunities for solidarity between Ethiopians and other people of African descent. It is practically very difficult to find common political ground with someone whose freedom and sense of self would unravel without a colonized or enslaved person to look down upon. Toni Morrison famously said she pities those who believe in white supremacy because they seem to have nothing without it. She asked, "what are you without racism? Are you any good? Are you still strong? Still smart? You still like yourself?" She added, "if you can only be tall because somebody's on their knees, then you have a serious problem" (Morrison 2019). As with Morrison's whites, so with exceptional non-black Ethiopians.

The construction of Ethiopian non-blackness is two-way: invitation and acceptance; entreaty and self-vaunting. In many acts, small and big, a large slice of Ethiopians alternately accept and refuse the crumbs from the high table of whiteness, alternately construct or eschew a non-black self-identity. In practical political terms, the alternatives are often straightforward: casting one's lot through political struggle with African Americans, as did Haile Gerima, Nipsey Hustle or the Washington State politician Girmay Zahilay, or the literary scholar Dagmawi Woubshet $(2010,2018)$, among many others, all of whom have in their own way refused the incitement to whiteness.

The ones who accept the incitement are no less numerous. A corporate climber and family friend once sidled up to me at a book event and said, "You know you're not like them, right? In this country, you have the benefits without the baggage." This whispered incitement echoed other similar sentiments I have heard from Ethiopians before. His success in corporate America was surely two-way: eager tokenism on the employee side, sly diversity-speak on the employer slide.

Little about this is new. In the immediate aftermath of Ethiopia's victory over Italy, European and American newspapers carried reports claiming - in a sharp turnaround from reports just earlier that year - that Ethiopians are actually white, not black. For the Euro-American ideology of absolute white racial superiority to remain solvent, the exception had to be rationalized. The most common rationalization was the reclassification of Ethiopians as white. Indeed, even in the run-up to fascist Italy's invasion of Ethiopia thirty-five years later, W Perry George, a United States State Department Official, wrote, reviewing a Time magazine article from earlier in 1935, that "The Ethiopian nation is referred to as negroid. While there is a large negroid population in Ethiopia, the ruling class is scientifically and obviously not negroid. This is an error that Time appears to have fallen into along with the negro organs quoted in the same article" (George, 1935). The nature of whiteness, of racial elitism, has changed, but the fundamental 
Michael Girma Kebede

grammar of self-hierarchization in a racialized schema has remained. Its persistence has been a potent weapon in the hands of our oligarchs and their handlers.

\section{Exemplary blackness: Victim-blaming and social distancing}

The other form of exceptionalism that Adom Getachew identifies, that of "exemplary blackness", produces another form of conceit no less solidaritydestroying than exceptional non-blackness. Rooted in the notion that Ethiopia is "the sole African country that was never colonized," this form of exceptionalism saturates vernacular discourse among Ethiopians. The examples are legion. Abiy Ahmed, Ethiopia's Prime Minister, leaned heavily on this trope in a recent address to the federal parliament where he rationalized and justified the government's counteroffensive against the Tigray People's Liberation Front in Tigray. ${ }^{5}$

TV commentary provides many more examples. For instance, in a recent TV interview, a conspiratorial, anti-Semitic pundit, during an animated stretch of commentary about Ethiopia and its international foes, Abiy Ahmed blurted, "they are no better than their grandparents, and we are no worse than our grandparents." He was arguing that Europe's subterfuge, channelled through the maze of Ethiopia's contemporary regional enemies, will be as bootless as the Italian colonial effort of the 1890s because Europeans are "no better than" those who lost in 1896, and Ethiopians "are no worse" than those who won. For this commentator, the idea of Adwa is not only historical; it is also prophetic. European defeat over a century ago predicts European defeat today. His type was familiar. Many like him had personally tried to ensure that 1896 lives in my bones and active memory, and that I wear that event as a shield against belittlement abroad, and against colonial or imperial designs on Ethiopia.

As a matter of practical political activity, exemplary blackness can undermine solidarity in at least two ways: victim-blaming and social distancing. The first way, victim blaming, blames black behaviour for black misery. Indeed, supposedly exceptional blacks themselves - whether Ethiopian or not - have deployed victim-blaming discourses that seem to absolve the racial capitalist system of blame, and to pin responsibility for black suffering on black people. Barack Obama, undeniably one of the contemporary world's most exceptional blacks, has, according to Keeyanga-Yamahtta Taylor, perpetrated something like

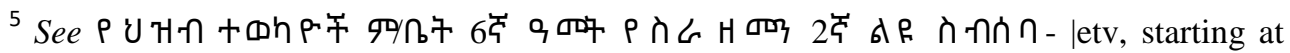
2:35-2:38. Retrieved from https://www.youtube.com/watch?v=I-43KpkmB24 
this type of argument. Taylor explains that Obama "has repeatedly failed to connect the sins of the past to the crimes of the present," after quoting him stating that a more perfect United States required African Americans "taking full responsibility for our own lives . . . by demanding more from our fathers, and spending more time with our children, and reading to them. ..." (2016, p. 138). It may very well be that that Obama enthusiastically embraced his blackness, including celebrating African American history and culture; but this pull-yourselfup-by-your-bootstraps discourse suggests that victims bear the primary responsibility for overcoming structural violence.

This type of discourse helps to reify the notion of radical separateness between groups of black people. The notion that those who are poor, incarcerated, or otherwise marginalized did something wrong to bring their misery upon themselves, or their failure to overcome misery is traceable to their misfeasance, suggests that there are fundamentally two classes of black people: a triumphant exceptional class, and a defeated, unexceptional class. Yet, this discourse misses radicals' observation that the whole machinery of racial capitalism has long thrived on the idea of exceptional blacks. Whether it is on an antebellum American plantation or in a contemporary Fortune 500, the corporate infrastructure of racial capitalism has long tokenized so-called exceptional blacks while subjugating many more blacks whose lives it touches.

Just like the triumphs of so-called exceptional individuals over structural adversity, Adwa can function as a collective story of triumph over the settler colonial wing of European racial capitalism. A solidarity-destroying implication of this line of reasoning is that Ethiopia has something those who failed to withstand Europe's late nineteenth century onslaughts lack. Rather than asserting that all people of African descent and their non-black comrades were, in their own disparate ways, responding to the incursions of a global racial capitalist order, this line of reasoning implies a radical difference between other experiences of racialization that made black subjects out of non-Ethiopian black people.

Social distancing is another way that black exceptionalism undermines solidarity. Before the COVID-19 pandemic popularized the term, social scientists used the term "social distancing" to describe the behavior of immigrants in the West who "distance" themselves from poor black Americans and other marginalized groups (Jackson 2010). Social distancing encompasses not just the spatial distancing lately counseled by public health experts, but also spiritual, religious, cultural, lexical, romantic, and other forms of distancing. Although coincidental, the public health resonance of the phrase is instructive, for those who practice racialized social distancing treat those they flee with all the manic 
nervousness of mass hypochondria. Racialized social distancing confirms and reinforces the transformation of racial hierarchy from white/non-white to black/non-black. The idea here is that whereas racial capitalist ideology once upon a time measured social power through proximity to whiteness, in the last half century or so it has increasingly measured social power through distance from a certain abject form of blackness. ${ }^{6}$ Granted, these two ideas have constituted each other since the inception of white supremacy in the west; but the point here made by scholars like john powell ${ }^{7}$ (2012, p. 27) and George Yancey (2003, pp. 149164 ) is one of emphasis, of the increasing emphasis on exceptional blackness at the expense of a supposed unexceptional blackness.

Part of the story of Ethiopian immigration to the United States seems to confirm this thesis. Haile Gerima's famous row with Ethiopians in the Washington D.C. area over the selection of designation of a part of Washington D.C. as "Little Ethiopia" is a case in point. During the 1980s, Gerima argued against Ethiopian immigrants' efforts to reshape parts of the then majority-black city in Ethiopians' cultural image. His gripe was that his fellow Ethiopian immigrants' organizing effort bypassed the local African American population and consulted instead only with powerful white city officials. Gerima lost the Battle; Ethiopian cultural icons proliferated throughout Washington D.C. Of course, the Ethiopian immigrants were simply behaving the way assimilationist quarters of previous waves of immigrants have behaved before them. But for Gerima, the blackness of the Ethiopian immigrants should have inspired greater concern for African Americans.

My own adoptive home of Maine further substantiates this story. According to the Washington Post, Maine's black population is just under half black immigrant and just over half African American. In no other state in the United States do black immigrants make up a higher share of the black population. This only became so in the last three decades. Maine saw a relatively large influx of African immigrants in the 1990s for a complex set of reasons. Many hundreds of these immigrants were Somalis who had arrived in the United States years prior, and had built lives in other states. In my past few years of activism, lawyering, and

\footnotetext{
${ }^{6}$ There is some social power that comes from proximity to, and appropriation of, cultural blackness. On that question, I have nothing to add to the analysis in Love \& Theft: Blackface Minstrelsy and the American Working Class, where Eric Lott (2013) argues in part that minstrelsy and appropriation allow repressed nonblacks to vent and to feel better than those from whom they steal.

7 john powell, taking his cue from bell hooks and others, spells his name entirely in lower case letters.
} 
living in Maine, more than one black African immigrant - some Somali, some from Great Lakes countries - has openly confessed to me that the reason they came to Maine from places like Atlanta is "to get away from African Americans." While none of them would describe themselves as non-black, they found it expedient to distance themselves from a certain form of blackness. This is certainly not the behavior of all or most Ethiopian immigrants; but it represents an important tendency.

This behavior of social distancing, it must be said, is not necessarily a manifestation of conscious anti-blackness; it can also be understood as an effort to escape depredations of racial capitalism that are especially pronounced where large numbers of black Americans live. Poor housing, unemployment and underemployment, food deserts, air pollution, lead poisoning, police violence, and other disasters imposed on black life in the West come to constitute, in the immigrant's mind, shorthand for blackness itself. Yet, tellingly, none of the black immigrants who described to me their decision to socially-distance from black Americans blamed white supremacist, patriarchal, racial capitalism for poor housing, joblessness, violence, and the other social ills they fled. Instead, they used terms like "black American" and "African American" as a synonym for the social ills they fled. Many in my own Ethiopian extended family counseled the same to me through suggestions like "don't assimilate into black American society." This tendency is by no means definitive or universal; but it exists, shapes behavior, and cries out for analysis.

The solidarity-destroying implications of social distancing are manifold. One very straightforward way this happens is that Ethiopian flight from nonEthiopian blacks dramatically reduces chances for waging a shared struggle against shared harms. The sheer fact of willed social separateness from African Americans (and other black people), and of some Ethiopians' spurning of African American social life, reduces opportunities for developing a shared analysis, shared strategies, and shared political formations. Almost all forms of discrimination that Ethiopian immigrants suffer were, at some point, and to a large extent still, staples of black American life. Not only do social-distancing Ethiopians deny themselves the insights that African Americans have won from their longer-lived and more intimate experience with racial capitalist patriarchy, but they also deny themselves the political power reflected in the truism that larger numbers in struggle make collective liberation more likely.

Social distancing exists in a dynamic relationship of mutuality with victimblaming discourses. A fundamental underpinning of social distancing of the type described here is that there is a unique and singular community to preserve, a 
community that history has made exceptional. The basis for exceptionalism analyzed here is the victory at Adwa, but the retention of an Ethiopic script, a form of Christianity traceable to the fourth century, or simply the retention of more features of an African heritage - language, clothing, certain forms of sociality can just as well function as the unspoken chain that is thought to fence the socialdistancing community. A tragedy of exceptional blacks social distancing from supposedly unexceptional blacks is that the former will, sooner or later, face the abuses and condescension that have assaulted the latter for centuries, and over which the latter possess some methods of endurance. Put another way, the socialdistancing behavior of supposedly exceptional blacks only delays the inevitable; sooner or later you, or someone you love, will receive the cruel end of racial capitalist patriarchy. Perhaps then, you will wish you were on better terms with your black radical siblings.

To recap, some Ethiopians are at risk of remembering Adwa as a basis for establishing an exceptional identity. In Adom Getachew's analysis, this exceptional identity has at least two forms: exceptional non-blackness, and black exceptionalism. I have identified two facets to each form of exceptionalism. Exceptional non-blackness has the dimensions of "uncolonized" and "unenslaved" in the Atlantic slave trade. black exceptionalism has the dimensions of social distancing and victim blaming. My multidimensional conceptual analysis is nonexhaustive. There may be still more facets to forms of exceptionalism that Adom Getachew has identified. What is more, I have focused on the seediest dimensions of exceptionalism, and of Adwa remembrance, not on the most hopeful, or inspiring, or promising. I have done this because analyzing the seedy is necessary to understand barriers to solidarity. I have also done this because the seedy dimensions of exceptionalism are true to my experience - they are true to my Tizita.

The next section of this paper sketches out an alternative method of remembrance: the black radical imaginary. This method of remembrance rejects the idea that different encounters with racial capitalist systems constituted radically and ontologically different types of black people. There are no exceptions in the black radical imaginary, only different rooms in the great mansion of resistance. Adwa is a kind of anteroom in this mansion, and an event whose inheritors are the many colored, many tongued, many gendered resistors to today's manifestations of racial capitalist plunder. 


\section{The black radical imaginary}

Human beings habitually construct and depend on a mental world that reinforces a positive self-image. This activity is crucial for individual and collective psychological health in a world that maligns relatively immutable traits at the symbolic and material levels. During the past five centuries, and perhaps longer, ${ }^{8}$ people of African descent have been gradually integrated into a world system where they form the ground upon which other groups of humans construct false ideas of inherent supremacy in order to allocate resources, rights, entitlements and duties - even the very privilege of humanness. Indeed, for much longer, human beings have maligned other human beings' gender and other embodied traits. The maligned routinely, and of necessity, fashion some positive counter-image of their inherent dignity, strength, and humanness. The black radical imaginary describes some of this psychic space for those of African descent, and those not of African descent but committed to the abolition of racial capitalist patriarchy.

The black radical imaginary is an assemblage of events, personalities, and historical reference points upon which people of African descent and their radical non-black comrades construct a provisional sense of place, dignity, and tailwind in the world. It is a psycho-emotional repository from which people fighting racial capitalist patriarchy draw dignity and sustenance. In conceptualizing the black radical imaginary, I draw on the recent work of political theorists Paula Diehl and Craig Browne, who described the political imaginary as "a collective structure that organizes the imagination and the symbolism of the political, and therefore organizes the instituting process of the political as well" (2019). Diehl and Browne theorize the political imaginary based on Charles Taylor's theorization of the social imaginary in his 2004 book, Modern Social Imaginaries, where Taylor stresses the relational dimension of the way people imagine their social existences, "the expectations that are normally met and the deeper normative notions and images that underlie these expectations" (Taylor, 2004; Diehl \& Browne, 2019). Diehl and Browne took Taylor's concept and focused it on political life, which makes it more relevant for my purposes. Browne in particular emphasizes the tendency of the political imaginary to hierarchize along lines of "gender, types of labour, or ethnicity," a tendency of profound relevance to conceptualizing the black radical imaginary (Browne, 2019, p. 4).

\footnotetext{
${ }^{8}$ Frank Wilderson III argues that the roots of anti-Blackness lay not in the advent of the Atlantic slave trade, but in the seventh century in the Arab-led East African slave trade. (2020).
} 
The black imaginary describes some of the psychic content of what Cedric Robinson referred to as the black radical tradition. In Black Marxism, Robinson outlined the historical roots and practical and conceptual forms of racial capitalism, a term he used to describe a global system of production and subjugation (1983). He argues that racial capitalism has roots in a racialized division of labor extant in Europe long before slavers forced Africans to the Americas. Robinson described those who belong to the black radical tradition as encompassing, but exceeding, the Marxist tradition. The Marxist tradition, he argued, has historically offered too little utility for the problems of racial subjugation; black radicals like Claudia Jones, WEB Du Bois, and Richard Wright took the Marxist tradition and enlarged it to include a set of radical political, cultural, and social programs that address capitalism's racial dimensions. What I'm describing as the black radical imaginary differs from Robinson's analysis in its temporal scope.

While Robinson's conceptual formulation is time-limited to the world after the Atlantic slave trade, the black radical imaginary spans all time and space, encompassing events and personalities that inspire those who labor in the black radical tradition. The rise of Terence from enslaved Roman to celebrated playwright, Bar Kokhba revolt against the Roman Empire, the Israelite Exodus, Maccabees' defeat of the Seleucids, Saladin's defeat of the Crusaders in 1187, the Haitian Revolution from 1791 to 1804 and the many Caribbean revolts that followed it, the Bahia Rebellion in 1822-1830, the Sharpe Rebellion in 1831, the Battles of Little Bighorn in 1876, Isandlwana in 1879 and Khartoum in 1885, Nat Turner's rebellion in 1831, John Brown's raid of Harper's Ferry in 1859, have all formed, in numerous times and places, for the anti-imperial peoples of the world, important evidence of the essential indeterminacy of history, and of the egalitarian instinct in political struggle. These armed rebellions are no less a part of the black radical imaginary than the ability of a people to persist, retaining key features of their cultural inheritances through harrowing circumstances. Histories of Africans cast in terms explicitly designed to rebut white supremacist historiography all enter into the fold of the black radical imaginary, since these histories, flawed as they are, have supplied a sense of pride and psychic protection to people whom hierarchizing discourses would consign to some form of inferiority.

The concept I use here is also inspired by, but significantly different from, Robin D.G. Kelley's concept of the black radical imagination. In Freedom Dreams, Kelley writes that "the map to a new world is in the imagination, in what we see in our third eyes rather than in the desolation that surrounds us" (2003, p. 2). The concept Kelley develops to describe this mental map of the features of a new world is essentially programmatic; from the wreckage of our foregone 
struggles, it cobbles together a program for the reconstruction of our global order. Kelley surveys liberation "movements [that] crashed against the rocks, wrecked by various internal and external forces" $(2003$, p. 3). He investigates the visions "they left behind..., however fragmented or incomplete, of what they wanted their world to look like." In doing so, Kelley hopes to "to reopen a very old conversation about what kind of world we want to struggle for" (2003, pp. 3-4). Kelley's concept says this is how the world should look. The concept I develop here says facing similar odds, this is what your forebears did, this is how they did it, and their deeds should give you solace and psycho-emotional fortification.

Indeed, even popular cultural artifacts like the movie Black Panther, although politically regressive (i.e., an embrace of patriarchal hereditary monarchy), have catapulted into the black imaginary within weeks of their release. This assemblage of reference points, unlike those excavated in Kelley's Freedom Dreams, provides no political blueprint. They do not provide a ready-made template for strategy or tactics in struggle. But they do something else important: provide regularized psychological relief from the would-be totalizing and hierarchizing discourses of white supremacist capitalist patriarchy. Perhaps more importantly, they inspire. They provide strength in this world by supplying the psyche's inherent capacities for self-protection with a stream of references from the world of collective memory.

In earlier times when the world was less interconnected, the black radical imaginary took its cues from a narrower list. For instance, in the antebellum United States, biblical imagery supplied much of the content of the black radical imaginary. The same bible that slavers used to justify black subordination also says, at Psalm 68, verse 31, "Princes come out of Egypt. Ethiopia stretches forth her hands unto God." This shred of revelation functioned as a potent method of collective ego-fortification. It fuelled Ethiopianism, a nineteenth-century black pride and institution building movement that rebuked ideas about black inferiority. Then as now, the ego exists both within and outside of time and space; it floats in the atemporal psychic spaces constituted by cultures, languages, and power relationships. The Buddhist Tara Brach has compared the ego to a spacesuit. Like a spacesuit, the ego's primary function is to keep a person, or a group of people, safe from external dangers. The black radical imaginary has functioned as a source of psychic safety. But it has also lit the morale of vilified people, opening a potent mental and emotional space between consignment to inferiority and experiences of transcendence. 


\section{Adwa in the black radical imaginary}

On March 1, 1896, an African army vanquished a European army in Adwa, a hilly town in northern Ethiopia. Of the soldiers arrayed against Ethiopia, only about half were white. The rest were black Africans who looked and spoke like a large swathe of Menelik's army (Jonas, 2015, p. 186). The black fighters for Italian settler colonialism were known as Askari, an Arabic term used to refer to African troops who fought for Europeans, or by the local term "Banda," which carried the same resonance as "Askari" and is still deployed in Ethiopia to smear someone as a traitor.

Blacks were present in the Italian army, and some whites were present as advisers in Menelik's cabinet. The best known of the whites on Ethiopia's side is probably Alfred Ilg, whom Emperor Menelik hired when he was still king of Shoa. Ilg, a polyglot Swiss engineer, played a key propaganda role in Ethiopia's effort to defend itself. He gave interviews to European papers in French, German, Italian, and English. His interviews helped to enshrine in European minds an image of Ethiopia as an African Switzerland, and to help turn much European public opinion against the Italian adventure (Jonas, 2015, pp. 13, 148-149). This is not to deny the fact that the Ethiopian side in this anticolonial resistance was led by, and for, black Africans; it is instead to emphasize the fact that some Italians betrayed Italian fascism and some Europeans betrayed European colonialism - and that this betrayal is an instructive part of the historical record.

Ilg was not the only European who contributed to the Ethiopian effort. Casimir Mouldon-Videlet and activists like Antonio Vigo, and many young Italians who marched in the runup to war chanting "Viva Menelik" and criticizing the colonial effort, exposed the lack of European unanimity behind Italy's settler colonial ambitions (Jonas, 2015, p. 130). White supremacist ideology, as well as other ideologies of ethnic or racial supremacy, draws sharp boundaries around racial groups, branding these anti-colonial Italians as traitors, as stray bees from the racial hive. In his Elements of the Philosophy of Right, Hegel assigns to "Germanic peoples" the world-historical task of uniting "divine and human nature," of reconciling "objective truth and freedom." (Hegel, PR, at 379). His Philosophy of History discloses that by "Germanic," he means not merely German, nor solely Nordic, nor just Scandinavian, but also the peoples of England, France, Italy, Spain, Portugal, and even the Magyars and Slavs of Eastern Europe. (Hegel, PH, 421/348/349/350). Thus, three quarters of a century before Adwa, one of Europe's foremost philosophers painted his continent's inhabitants as one people fated for triumph and destined for world leadership. But history in Adwa, as well as in the maroon societies of the Americas, as well as in the U.S. civil war, and in 
numerous other places, tells a multicolored, polyphonic story. The constituency of Eurocentrism and white supremacy includes many unwilling members. Some faced death to fight an ideology that purports to enshrine and advance their material and symbolic interests. This point finds thorough vindication in Adwa. Eurocentrism had European enemies, people whom Hegelian prognostications left unpersuaded.

In a different way, Menelik himself and some of his closest advisors - Ras Makonnen chief among them - were either closely ingratiated with Europeans or openly Europhilic (Jonas 2015, pp. 82-88). For all her suspicions of Europe, Tayitu also kept Ilg close, handing him lists of things to bring back from Europe. Menelik's own proximity to Italians in the 1870 s and 80 s was a crucial means through which he amassed a large supply of armaments (Jonas, 2015, pp. 21-22). Indeed, there is some evidence that he was a part of the Italian strategy to support an underdog client and rule the region through him. But when the time came to choose sides, he chose against Italy, his erstwhile sponsor (Jonas, 2015, pp. 47-48).

The fact that neither side was racially homogenous stands as a rebuke to the photo-negative of Hegel's above-quoted point: ideas about racial homogeneity that continue infecting liberation movements around the world. Neither side was all black or all white. But one side fought for the disproportionate benefit of blacks, and the other side fought for the disproportionate benefit of whites. In fact, whites were important in Ethiopia's soft power efforts. Raymond Jonas explains that "Ethiopian triumph owed almost as much to the soft power of propaganda as to blood and steely might" $(2015$, p. 2). Liberation discourses that aim to homogenize the entire population of liberation fighters, regardless of whether these fighters struggle in the field of political or military or cultural battle, have often also reproduced patriarchal political cultures.

Adwa also rebukes patriarchal and male supremacist ideologies of struggle. Tayitu's strategic distrust of Europeans - not just Italians - was important in securing victory for Ethiopia. ${ }^{9}$ In addition to maintaining a healthy skepticism of European intentions, Tayitu also fan Ethiopian morale during battle time (Jonas, 2015, pp. 21-22, 187, 213-215). Thus, the triumph at Adwa is an exemplar of what black radical feminists in the West have been saying for decades, that women and femmes have played crucial roles in the struggle against racial capitalist patriarchy.

Adwa also contains seeds of a political imagination that does not rely excessively on prisons and police to solve social problems, perhaps forming

9 "A blend of Tayitu's ardent maximalism and Menelik's brilliant gamesmanship culminated in the triumph at Adwa" (Jonas, 2015, p. 2). 
something of a template for what Robin Kelley refers to as the radical imagination. Long before the worldwide boom of mass imprisonment and securitization, Ethiopia treated Italian prisoners of war with exemplary humanity. Italian prisoners were not thrown in dungeons or tortured or turned into spectacles of humiliation. Instead, they were placed in homestays throughout the country. There was, to be sure, a high premium on good treatment of captives, since an injured, humiliated, or deceased captive made a less persuasive bargaining chip than a captive who was alive and healthy. Nor should we overstate the kindness with which prisoners were treated. Ethiopians did find creative ways to humiliate Italian prisoners. At water stops in the long post-battle march from Adwa to Addis, "Ethiopians drank first, then they watered the animals. The prisoners drank last" (Jonas, 2015, p. 240). Perhaps most dastardly, and despite Menelik's orders to leave these body parts intact on prisoners of war, one historian estimates that approximately $7 \%$ of wounded Italians, or 30 out of 461, returned home castrated (Jonas, 2015, p. 227).

For Ethiopians in the diaspora, as well as for social movement builders in Ethiopia looking to tap into a global network of radical movement building, Adwa has some relevance. At its best, Adwa can inspire resistance to domination and humanity in the treatment of adversaries, even the treatment of the ultimate enemies of would-be colonizers. an inspiration while those narrativizing Adwa can draw inspiration from BLM.

\section{Adwa in Ethiopia's plurinational present}

Up until now, this article has more or less ignored Adwa's explosive political and discursive resonances within Ethiopia, and among Ethiopia's non-Tigre and nonAmhara language groups, but especially Ethiopia's largest ethnolinguistic group, the Oromo. This section of the paper will illustrate and find a way out of those tensions through analysis of three cultural artifacts: Gigi's song Adwa, Teddy Afro's song Tiqur Sew, and Tsegay Gebre Mhedin's poem Wa! Yachi Adwa. Several incisive scholars have pointed a way out of our possible explosive tensions. The bottom line is this: it matters how stories are told or silenced. What is more, the heroes or heroines matter no less than the story's model of heroism. We must decouple Adwa from hagiography or Great Man history. In telling of Tayitu, we must not ignore class tensions and her own hierarchizing colorism. In 
recounting Adwa, we must tell the variegated, polyphonic story that is both truer to 1896 and to the nature of political life in Ethiopia and elsewhere. ${ }^{10}$

A form of Ethiopian nationalism predicated on a hagiographic, Menelikcentric reading of Adwa has rightly been under assault from movements for ethnolinguistic recognition and redistribution. Hagiography, it must be said, is simply one form of exceptionalism, a form that emphasizes the supposedly exceptional or great deeds by supposedly great or exceptional people. Hagiography reads history itself as a progressive succession of those great deeds and people. Menelik-centrism is a non-starter for many Oromos.

Hassen Hussein, Mohammed Ademo, Awol Allo and others contend that the official narrative of Adwa has historically sidelined the role played by all language groups except the Amhara and Tigre (Hussein \& Ademo, 2016), (Allo, 2019). Not only did Emperor Menelik achieve his imperial status through a series of bloody wars of conquest, but "[ $\mathrm{t}]$ he Battle of Adwa enabled Emperor Menelik II to consolidate his fledgling empire, using the same violent tactics that forged European colonial empires in Africa, Asia, and South America" (Hussein \& Ademo, 2016, p. 23). This point identifies a key conundrum in Ethiopian political life. Hussein and Ademo's way out: foreground the entire cast of heroes of the Battle, especially those whom Menelik had violently subjugated before inducing them to fight against the Italian army. Under-emphasized in Hussein and Ademo's article is what Paulos Milkias called "the anonymous Ethiopian . . . whose name is no longer known" (2005, p. 80). Milkias's anonymous Ethiopian must be disaggregated by ethnolinguistic identity; only then can we get away from a flattened, ethnicity-neutral Ethiopianness that does nothing to curb Tigre and Amhara centric accounts of Adwa.

Unfortunately, some prominent Ethiopians continue to celebrate an unproblematized, Menelik-centric Adwa. In perhaps the most prominent contemporary example, one of Amharic music's megastars, Teddy Afro, made the very first song of his 2012 album, Tikur Sew (or "black person") a homage to Menelik. Throughout the song, the colossal role played by Muslim and nonAmhara warriors are mentioned only in passing.

To be fair, the song does give Tayitu her due, and Tayitu is both Oromo and a woman. Both those identities - Oromoness and femininity - have historically

${ }^{10}$ Cedric Robinson, Terms of Order. Robinson here takes political science to task for perpetrating "the myth of leadership." Individual leadership is a methodological construction of very specific discursive lineages and obscures more than it illuminates. 
been nondominant in official Ethiopian historiography. Although Queen Sheba figures prominently in traditional Ethiopian historiography, as does Tayitu herself, the history of Oromos qua Oromos has been marginalized at best. Another song titled Taitu, by Aster Aweke featuring the group Yegna, makes the queen its centerpiece. Yet, as with Teddy's version, the Yegna song says nothing about Tayitu's colorism. ${ }^{11}$ Teddy's song also triumphs by repeatedly describing Menelik as a "black person," the album's title, helping rebut a form of Ethiopian exceptionalism (described above) anchored by the historical memory of Adwa. Yet another more inclusive path is possible from Teddy's Menelik-centric one; Teddy's concession to blackness alone is not enough to be inclusive of Oromo and other marginalized voices.

The Ethiopian, ethnically Oromo poet and playwright, Tsegaye-Gebre Medhin, took a more inclusive path in his Amharic poem about Adwa written in Yekatit 1964, or February or March of 1972, two years before Teddy Afro was born. In that poem, titled "Wa! Yachi Adwa!" (translates as "Beware! That Adwa!"), Tsegaye does not even mention Menelik once as Menelik. Instead, he alludes to a cast of characters prefixing "Abba," a term that means "elder" in Amharic, to each name: Abba Nefso, Abba Mechal, Abba Dagnew (Menelik), Abba Kagnew, and the all-inclusive Abba - Belew - Belew - Belew ("Abba Attack - Attack - Attack!"). Menlek is less mentioned than alluded to with a prefix, "Abba," that submerges him in a broader, multiethnic cast of characters. ${ }^{12}$

Gigi's song Adwa goes still further. Against a gauzy, ominous instrumental background, she opens on a humanistic note:

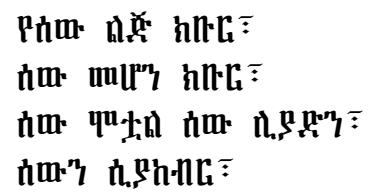

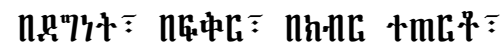

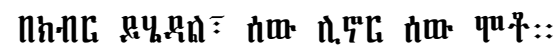

\footnotetext{
${ }^{11}$ Apparently Tayitu composed her inner circle of "women with darker complexions, the better to show off her own light coffee skin" (Jonas, 2015, p. 22).

12 The whole poem is available here: http://katnafeskeatnaf.blogspot.com/2017/03/blogpost_27.html
} 
[Human life with respect;

To be human is to have dignity;

Humans died to save humans;

Respecting humans;

Called with kindness, love, and respect;

Goes with respect, people to live, for people to die.]

The first quarter of Gigi's lyrics teem with timocracy and an unspecified, universalistic humanism. The word " $\dot{\emptyset} \boldsymbol{D}$-" ["human"] appears in almost every line of the first half of the song. Unlike Teddy and Tsegaye, she singles out no individual heroes. Instead she starts by referencing an abstract "human," an Archimedean position from which she asserts a dignitarian and timocratic morality. Her abstract human actually captures a strong tendency among a significant share of Ethiopians: framing an issue from the vantage of a universalistic, unspecified humanism. Of course, there is no such thing as an abstract human, only concrete beings in one or another form of relationship. This fact rears its head soon after the universalistic stretch at the start of Gigi's song, when her lyrics take a turn from the sacrificial human to the martyred $\triangle 7\}$ (or comrade), then to the anthropomorphized and gendered space of Adwa, whom Gigi insists must confess how Gigi stands before us today. This stretch is worth pausing over:

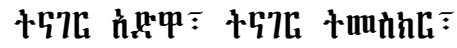

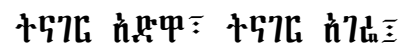 \\ ก้”

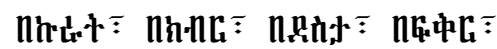

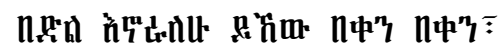

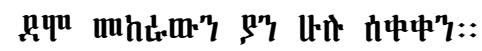

[Let Adwa tell; let her tell, let her confess;

Let Adwa tell; let my country tell;

How I am standing before you today.

With pride, with respect, with joy, with love;

I live in victory day by day,

All that heartache, all that horrification.] 
The universal is anchored in the particular. The universal human is made possible by the particular battle. In her telling, the battle is no dusty figment of memory, but a living and breathing place that speaks into existence freedom, dignity, pride, respect, joy, love, and Gigi herself. Here is the black radical imaginary in verse, a record of the psychic space forged in triumph over a colonial attempt. The song drips with all the things that sovereignty preserved: forms of joy, forms of pride, forms of respect, and forms of love that successful Italian colonialism might have overshadowed. The song's final verse weaves the Ethiopian with the African with the black and exemplifies the trans-historical, outside-time-and-space nature of the black radical imaginary:

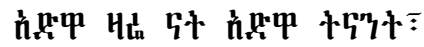

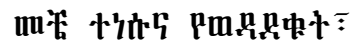

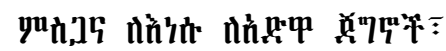

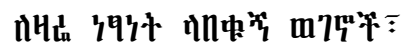

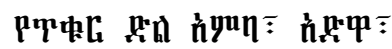

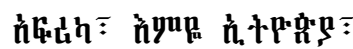

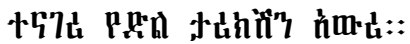

[Adwa is today, Adwa is yesterday,

They haven't arisen, those who fell,

Gratitude for them, for the heroes of Adwa,

For today's freedom, for which my compatriots prepared me,

The apex of black victory, Adwa;

Africa's, mother Ethiopia;

Speak, of your triumphant history, tell.]

The black and the African and the Ethiopian blend into one another in this retelling of Adwa. Gigi's lyrics are true to human psychology: the individual, and the collective, ego is atemporal; "[it] is today, [it] is yesterday." The symbology at work in these words attempts to show how identity is constituted in history. Juxtapose Gigi's lyrics with this passage from Frank Wilderson's Afropessimism:

... Black labor is not the possession of Black people any more than we possess our bodies. Nor are we dispossessed of land like the Irish or the Native American or Said and Nidal's Palestinians; notwithstanding the fact that, save Ethiopia, all of Black Africa has 
been colonized at one time or another. The antagonist of the worker is the capitalist. The antagonist of the Native is the settler. But the antagonist of the Black is the Human being (2020, p. 241).

Wilderson's overall contention is that there is no Human without a nonHuman black, and Gigi's point is a countervailing one: there is blackness that is also Human, if we perceive blackness from the standpoint of historic triumphs against an attempt at white supremacist subjugation and erasure. To Wilderson, "the Black is a sentient being though not a Human being" (2020, p. 245). Yet unlike some Ethiopian exceptionalists, who take a version of this bait and claim non-blackness, Gigi does not say that the failed Italian colonial attempt left Ethiopians to stand alone as non-black humans. Instead, like Fanon, she finds that humanness emerges precisely in the moment of self-defense in the form of Adwa's preservation of Ethiopian sovereignty. Indeed, in the Western hemisphere, Afrodiasporic survival, and the ability of the enslaved to keep certain cultural and spiritual inheritances sovereign is perhaps more remarkable than Ethiopia's preservation of political sovereignty. In discerning the deep, ideational, libidinal structure of our world system, Wilderson perhaps gambles away too much; the black radical imaginary collects all of the spaces and events of triumph against the totalizing anti-blackness of the past several centuries and collates them in the atemporal? psychic space of collective ego-fortification.

Gigi, Teddy, and Tsegaye are three examples chosen for their broad representativeness. Teddy represents the acme of Menelik-centrism, cut with homage to Empress Tayitu. Tsegaye represents a paradoxical democratic hagiography, where everyone gets to be an Abba, and Menelik receives an allusive mention. Gigi represents the post-Menelik interweaving of the Ethiopian, the African, and the black. Of these, Gigi's is probably the most conciliatory, the one that comes closest to the post-hagiographic narrative mode. Indeed, her approach seems currently most popular. In Haile Gerima 1999 documentary, Adwa: An African Victory, competing claims of different language groups do not figure in any significant way. There is instead a multiethnic but definitely black Ethiopian army on one side, and a European army on the other side, with all the class and ethnolinguistic tensions suppressed. The current Prime Minister, Abiy Ahmed, references the event to shore up a common feeling of Ethiopianness, and to issue warnings to the country's adversaries. His particular reading of Adwa, like Negussay Ayele's reading, describes the event not as the triumph of one ethnic group's army over a European army, but as a legacy that belongs to "all Ethiopians qua Ethiopians -- and indeed, all Africans" (2005, p. 179). Theodore M. Vestal, 
Raymond Jonas, Paulos Milkias and still others share a similar view: Adwa belongs to no particular ethnic group, but to all Ethiopians, and to all black people (Vestal, Milkias, 2005).

But there is a problem in this narrative mode Those in nondominant groups in most societies have seen how ethnicity-blindness, or race-blindness, is often just the same old ethnocracy in new skin. It is thus imperative to follow the lead of Hussein, Ademo, and Allo and emphasize the role of the Oromo and other nonnorthern language groups in the triumph at Adwa.

To sum up, Menelik-centrism is an inherently alienating narrative mode. Obama's Lincoln-worship (whom, incidentally, Menelik also admired) and Hugo Chavez's Bolivar-worship share something similar. Lincoln ordered the largest execution of Native Americans in U.S. history. Bolivar led a land reform effort that was purportedly intended to benefit indigenous peoples, but ended up making large swathes of indigenous people landless. In Ethiopia, there is no denying, as Awol Allo reminds us, that "there is a significant portion of the public, including the Oromo, that remains ambivalent towards this historical moment" (Allo, 2019). There is at least one way viable out, a way attempted decades ago by Tsegaye, and later by Gigi: to make storytelling more democratic, to foreground the marginalized, especially those whose names nobody knows. Such a retelling of Adwa will help heal Ethiopia internally, and help make Ethiopians ready to act in solidarity with movements like Black Lives Matter.

\section{Conclusion}

Stories of Adwa have anchored multiple forms of exceptionalism that underpin some Ethiopians' sense of superiority and distinctiveness over others of African descent. This narrative mode goes hand-in-hand with certain toxic, solidarity destroying behaviors of immigrants to the West: social distancing and victimblaming. These forms of enacted exceptionalism, pushed by racialists, weaken social movements like Black Lives Matter. This article has argued that thinking of Adwa as part of the black radical imaginary promises a way out. The Battle was one node in a centuries-long process of resistance to racial capitalist patriarchy, a world system that still persists in many ways. Adwa must also be re-narrated if it is to be a viable source of solidarity among Ethiopians and within Ethiopia. Renarrating Adwa with an eye toward nondominant language groups, and toward the anonymous contributors to collective self-defense, is one way to tell a story geared toward an egalitarian politics focused on redressing historic wrongs. Gigi comes close in her song Adwa. The two approaches to Adwa - the world-systems retelling, and the non-hagiographic retelling - point to a way out of Tigre/Amhara 
domination among Ethiopians and a way out of anti-solidaristic forms of exceptionalism between Ethiopians and others of African descent. 


\section{References}

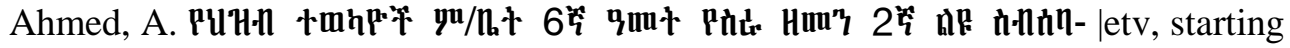
at 2:35-2:38.

Retrieved from: https://www.youtube.com/watch?v=I-43KpkmB24

Allo, A. (2019, March 1). How a major anti-colonial victory divided Ethiopia. Al Jazeera.

https://www.aljazeera.com/opinions/2019/3/1/how-a-major-anti-colonialvictory-divided-ethiopia.

Ayele, N. (2005). Adwa 1896: Who Was Civilized and Who Was Savage? In P. Milkias \& G. Metaferia (Eds.),The Battle of Adwa: Reflections on Ethiopia's Historic Victory Against European Colonialism. New York: Algora Publishing.

Browne, C. (2019). The Modern Political Imaginary and the Problem of Hierarchy. Social Epistemology, 398-409, doi.org/10.1080/02691728.2019.1652860.

Browne, C. \& Diehl, P. (2019). Conceptualising the Political Imaginary: An Introduction to the Special Issue. Social Epistemology, 33:5, 393-397. doi.org/10.1080/02691728.2019.1652859.

Campbell, E. (2015). Exploring Autoethnography as a Method and Methodology in Legal Education Research. Asian Journal of Legal Education, 3(1) 95105. doi.org/10.1177/2322005815607141

Du Bois, W.E.B. (1998), Black Reconstruction in America, 1860-1880. Free Press. Getachew, A. (2020). H-Diplo Roundtable XXII-3 on Zeleke. Ethiopia in Theory: Revolution and Knowledge Production, 1964-2016. Retrieved from https://networks.h-net.org/node/28443/discussions/6426905/h-diploroundtable-xxii-3-zeleke-ethiopia-theory-revolution-and\# Toc50760350

Getachew, A. (2019). Worldmaking After Empire: The Rise and Fall of SelfDetermination. Princeton University Press.

Gibbon, E. (1841). The History of the Decline and Fall of the Roman Empire, 3. Harper and Brothers.

Hussein, H. \& Ademo, M. (2016). Ethiopia's Original Sin. World Policy Journal, Vol. XXXIII, No. 3, 22-28. doi: 10.1215/07402775-3712981.

Jackson, R.O. (2010). Black immigrants and the rhetoric of social distancing. Sociology Compass, 4(3), 193-206. doi.org/10.1111/j.17519020.2009.00266.x

Jonas, R. (2015). The Battle of Adwa: African Victory in the Age of Empire. Cambridge, Massachusetts, London, England: Harvard University Press.

Kelley, R. (2003). Freedom Dreams: The Black Radical Imagination. Boston: Beacon Press. 
Lott, E. (2013). Love \& Theft: Blackface Minstrelsy and the American Working Class. Oxford University Press.

Marye, H. S. (2009). Ityo yawinnät and Addis Abäba's Popular Music Scene. Aethiopica 22, 96-123. https://doi.org/10.15460/aethiopica.22.0.1048

Medford, M. (2019). Racialization and Black multiplicity: Generative paradigms for understanding Black immigrants. Sociology Compass, 13(7). /doi/abs/10.1111/soc4.12717

Milkias, P. (2005). The Battle of Adwa: the Historic Victory of Ethiopia over European Colonialism. In P. Milkias \& G. Metaferia (Eds.),The Battle of Adwa: Reflections on Ethiopia's Historic Victory Against European Colonialism. New York: Algora Publishing.

Morrison, T. (2019). The Guardian, Toni Morrison's Powerful Words on Racism. Retrieved from: https://www.youtube.com/watch?v=15MMmgwl1 V4.

powell, j.a. (2012). Racing to Justice: Transforming Our Conceptions of Self and Other to Build an Inclusive Society. Bloomington \& Indianapolis: Indiana University Press.

Robinson, C. (1983). Black Marxism: The Making of the Black Radical Tradition. Chapel Hill \& London: The University of North Carolina Press.

Selden, D. (2013). How the Ethiopian Changed His Skin. Classical Antiquity, 32(2), 322-377. doi:10.1525/ca.2013.32.2.322

Shelby, T. (2005), We Who Are Dark: The Philosophical Foundations of Black Solidarity. Harvard University Press.

Taylor, C. (2004). Modern Social Imaginaries. Duke University Press.

Taylor, K.Y. (2016) From \#BlackLivesMatter to Black Liberation. Chicago, Illinois: Haymarket.

George, W.P. (1935) State Department Decimal Files, 1930-1939, 711.84/13. George to Secretary of State,

4 April 1935, available at https://catalog.archives.gov/id/87833266, citing Time (1935, February 25), Negroes v. Blackshirts.

Wallerstein, I. (1974). The Rise and Future Demise of the World Capitalist System: Concepts for Comparative Analysis. Comparative Studies in Society and History, 16(4), 387-415. doi:10.1017/S0010417500007520

Wilderson III, F. (2020). Afropessimism. New York: Norton.

Woubshet, D. (2018). Black Meets Black: Encounters in America. James Baldwin Review, 4, 63-71.

Woubshet, D. (2010). Gleaning Ethiopia. Callaloo, 33(1), 199-101.

Yancey, J. (2003). Who is White? Latinos, Asians, and the New Black/Nonblack Divide. Lynne Rienner. 
Michael Girma Kebede

Zeleke, E.S. (2019). Ethiopia in Theory: Revolution and Knowledge Production, 1964-2016. Leiden, Boston: Brill. 